\title{
BANK OF RUSSIA LIQUIDITY MANAGEMENT OF THE BANKING SECTOR: OBSERVATIONS BASED ON THE PAST THREE YEARS EXPERIENCE
}

Short-term money market interest rate management within the framework of symmetrical interest rate corridor is based on central bank open market operations that aim to compensate for a structural deficit and surplus of liquidity in the banking sector to make sure that the money market overnight interest rate is close to the middle of the interest rate corridor. The Bank of Russia practice in this form of management amid structural deficit of liquidity over the past three years has shown that the period average money market interest rate has been above the key interest rate by more than 0.5 p.p.s in half of 14 key rate periods.

The Bank of Russia upgraded its framework of interest rate instruments of the monetary policy in September 2013. ${ }^{1}$ When managing liquidity in the banking sector, the Bank of Russia seeks to make sure that overnight money market interest rates are close to the key rate. This operational objective can be achieved though employing monetary policy instruments and a set of rules and operational procedures, which is called the framework of symmetrical interest rate corridor. Not only does the interest rate corridor framework aim to keep fluctuations of market interest rates within limits, but it is also designed to drive them towards the middle of the interest rate corridor, that is, the key rate. ${ }^{2}$

The Bank of Russia considers auction-based 1-week repo operations as the principal instrument designed to regulate liquidity in the banking sector amid structural deficit of liquidity. When setting a limit on such operations, the Bank of Russia relies on forecast liquidity formation factors in the banking sector, "in an effort to meet credit institutions' needs for resources that enable them to meet the reserve requirements and to carry out payment operations". ${ }^{3}$ The Bank of Russia publishes its liquidity factors forecast for the ensuing week and a one-week repo auction limit on the date of auctionbased repo operations (on Tuesday).

The Bank of Russia relies on its published method of setting limits for auction-based repo operations. ${ }^{4}$ Should the Bank of Russia have correct assessment of the banking sector's liquidity demand, credit institutions' demand for standing facilities are relatively small. Also, note that in this case credit institutions do not have to seek a specific type of standing facilities (e.g., standing lending facilities) more frequently than the other (e.g., standing

1 On the framework of interest rate instruments of the Bank of Russia monetary policy / Bank of Russia. The information is dated 13 September 201 // http://www.cbr.ru/press/ PR.aspx?file=130913_1350427l.htm

2 Guidelines for the Single State Monetary Policy in 2016 and for 2017 and 2018 // Bank of Russia. PP. 9-10.

3 Guidelines for the Single State Monetary Policy in 2014 and for 2015 and 2016 // Bank of Russia. P. 23.

4 On setting limits on Bank of Russia open market liquidity provision (absorption) operations // Bank of Russia. http://www.cbr.ru/DKP/standart_system/DKP_limit.pdf, access date 30.07.2016. 
deposit facilities). This derives from the fact that within the framework of symmetrical interest rate corridor central bank open market operations provide the banking sector with liquidity equal to the mathematical expectation of structural deficit of liquidity in this sector, while credit institutions compensate for random liquidity shocks and for errors in liquidity forecasts ${ }^{1}$ by seeking standing facilities.

Liquidity management in the banking sector is more complicated because the Bank of Russia has other liquidity provision instruments in addition to auction-based repo operations; in particular, there is such a significant channel of liquidity provision as loans secured by non-marketable assets and guarantees. Figure 1 gives some insight into comparative volumes of banks' debt on repo operations (auction-based, and fixed-rate, operations) and of loans secured by assets and guarantees.

Consider the final "rising tide" for loans secured by non-marketable assets and the current downward period. In the period between 31 July 2013 and 15 January 2015, the debt on loans secured by non-marketable assets and guarantees was on the rise, there were some deviations though, and it was on the slide after 15 January 2015. What was the effect of upward and subsequently downward dynamics of loans secured by non-marketable assets on Bank of Russia principal operations of banking sector refinancing, that is, auction-based repo operations? To correctly forecast liquidity formation factors and to set a limit on auction-based repo operations, the Bank of Russia should consider in its forecast the dynamics of the second component of liquidity provision to the banking sector, that is, loans secured by non-marketable assets and guarantees. How successful was the coordination of limit on auction-based repo with anticipated dynamics of loans secured by nonmarketable assets? The question can be broadened because there are specialized instruments of refinancing and other types of credit operations: how successful was the conformity of the volume of auction-based repo operations with the dynamics of the portfolio of other refinancing instruments?

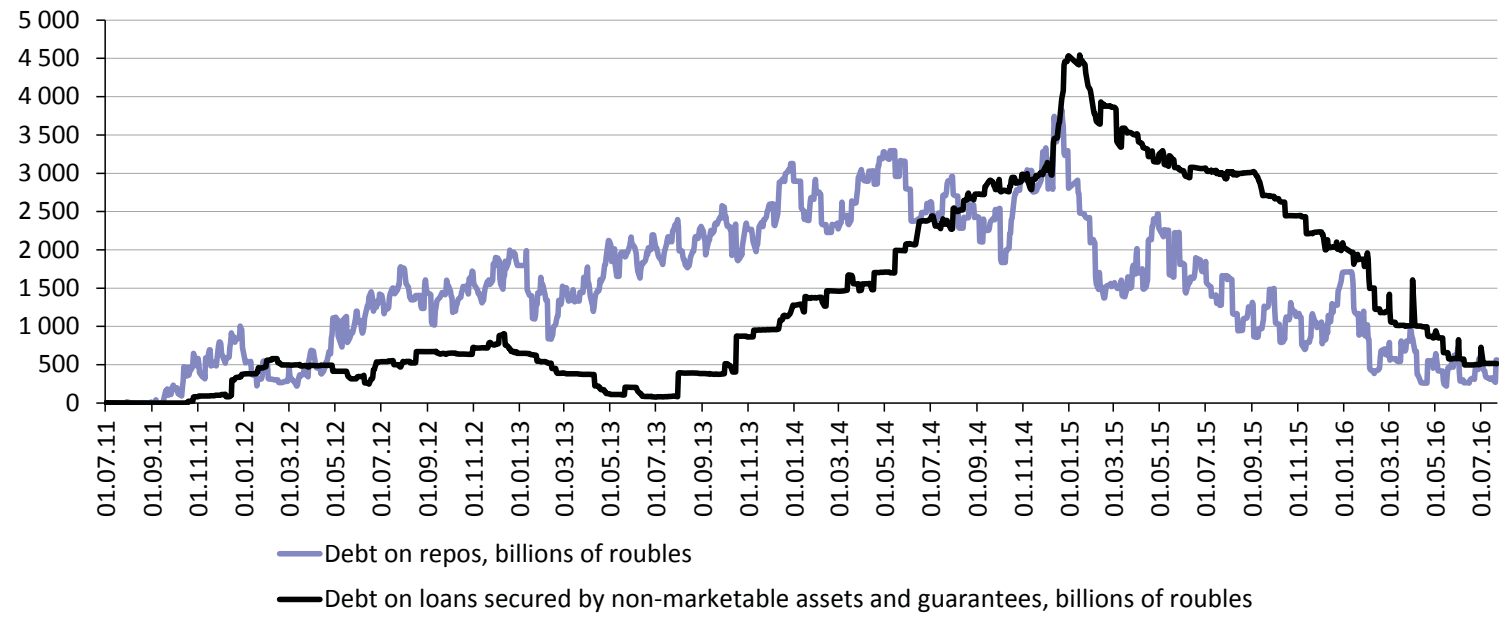

Source: The Bank of Russia.

Fig. 1. Credit institutions' debt to the Bank of Russia on repo operations and on loans secured by non-marketable assets and guarantees in July 2011 - July 2016

1 It is assumed that these shocks (and summary liquidity forecast errors) are distributed symmetrically around the zero mean value. 
Analyse the results of Bank of Russia auction-based repo operations during the two periods that we specify.

Two hundred and thirty seven (237) various-term auction-based repos were held during the "upward trend period" between 31 July 2013 and 15 January 2015, including 72 one-week repo auctions, 155 auctions for a term of 1-3 days and nine auctions for a term of 15, 21, 90 days and 12 months. The auction results show that the auction limit was not reached, the actual volume was less than the limit in 133 cases (56\% of the auctions). The forecast overstated the demand for liquidity at repo auctions, there were instances of above-normal limits.

Take for example the one-week repo auction results. In 2014, the volume was below the limit in 19 cases, it was below the limit by more than $\mathrm{Rb} 100 \mathrm{bn}$ at 10 auctions, and it was below the limit by more than $\mathrm{Rb} 500 \mathrm{bn}$ in three cases. Also, note that credit institutions often used more expensive standing lending facilities in big volumes on dates following the auctions where the limit was not reached. For example, on 25 March 2014, the volume at a oneweek repo auction was below the limit by $\mathrm{Rb} 663 \mathrm{bn}$ due to weak bidding. At the same time, on that day and on consecutive days of the week credit institutions borrowed daily $\mathrm{Rb} 400 \mathrm{bn}$ or more through FX swap operations (FX swaps) with the Bank of Russia. ${ }^{1}$

Things changed markedly during the period of downward trend for debt on loans secured by non-marketable assets. For instance, 88 repo auctions were held in the period between 16 January 2015 and 2 August 2016, most of which were 7-day repo auctions. The limit was not reached in only nine cases ( $10 \%$ of all the auctions). The demand was far above the set limit at many auctions during the same period, and the cut-off rate was markedly above the minimum bid rate (key rate), according to the auction results. No wonder that on the dates following the date of one-week repo auction credit institutions sought for (more expensive) Bank of Russia standing facilities to enhance liquidity. Table 1 presents data on 10 auctions to illustrate this trend in one-week repo auctions during the specified period.

Table 1

\section{ONE-WEEK REPO AUCTION RESULTS AND DEBT ON STANDING LENDING} FACILITIES

\begin{tabular}{|c|c|c|c|}
\hline $\begin{array}{c}\text { Auction } \\
\text { date }\end{array}$ & $\begin{array}{c}\text { Demand above } \\
\text { limit at auction, } \\
\text { billions of roubles }\end{array}$ & $\begin{array}{c}\text { Cut-off rate } \\
\text { above key rate, } \\
\text { basis points }\end{array}$ & $\begin{array}{c}\text { Average weighted debt on } \\
\text { fixed-rate repos in the following } \\
\text { five days, billions of roubles }\end{array}$ \\
\hline $\begin{array}{c}\text { 02.08.2016 } \\
\text { b.07.2016 }\end{array}$ & 128 & 111 & 201 \\
\hline 05.07 .2016 & 320 & 99 & 193 \\
\hline 28.06 .2016 & 244 & 96 & 194 \\
\hline 09.02 .2016 & 250 & 62 & 156 \\
\hline 12.01 .2016 & 1013 & 50 & 95 \\
\hline 13.10 .2015 & 331 & 82 & 297 \\
\hline 06.10 .2015 & 368 & 60 & 73 \\
\hline 29.09 .2015 & 506 & 61 & 142 \\
\hline 03.03 .2015 & 415 & 73 & 150 \\
\hline
\end{tabular}

Sources: The Bank of Russia, own calculations.

1 Own calculations using the data on repo auction results and on credit institutions' debt on operations with the Bank of Russia. The data are available on the Bank of Russia official website. 
These observations allow one to conclude that the forecast of liquidity formation factors in the banking sector that underlies Bank of Russia limits on one-week repo auctions is imperfect and its accuracy depends, among other things, on the quality of forecast changes in credit institutions' debt on loans secured by non-marketable assets and guarantees. The above mentioned Bank of Russia's document "On setting limits on Bank of Russia open market liquidity provision (absorption) operations" says nothing about harmonization of volumes of credit institution refinancing via various channels. The question remains open, although the results of regular auction-based operations of crediting against non-marketable assets for 3-month term at a floating interest rate are known on the date of setting the limit on one-week repo auctions. Additionally, there are non-regular auction-based operations and standing facilities whose results should be considered or foreseen, in particular because early repayment on them is possible, to achieve success in managing liquidity in the banking sector using principal auction-based repo operations and in maintaining the money market interest rate close to the key interest rate.

Descriptive statistics of money market overnight interest rate (MIACR) fluctuations are presented in Table 2 . The market interest rate was above the

Table 2

MIACR OVERNIGHT INTEREST RATE FLUCTUATIONS AROUND THE KEY RATE, \% P.A.

\begin{tabular}{|c|c|c|c|c|}
\hline Period of time & $\begin{array}{l}\text { Bank of Russia key } \\
\text { rate (repo auctions } \\
\text { minimum rate) }\end{array}$ & $\begin{array}{l}\text { Period average } \\
\text { MIACR overnight } \\
\text { interest rate }\end{array}$ & $\begin{array}{l}\text { MIACR interest rate } \\
\text { period average devia- } \\
\text { tion from key rate }\end{array}$ & $\begin{array}{l}\text { MIACR overnight } \\
\text { key rate stand- } \\
\text { ard deviation }\end{array}$ \\
\hline $\begin{array}{c}14.09 .2012- \\
12.09 .2013\end{array}$ & 5.50 & 6.06 & 0.56 & 0.36 \\
\hline $\begin{array}{c}13.09 .2013- \\
28.02 .2014\end{array}$ & 5.50 & 6.17 & 0.67 & 0.35 \\
\hline $\begin{array}{c}03.03 .2014- \\
25.04 .2014\end{array}$ & 7.00 & 7.81 & 0.81 & 0.23 \\
\hline $\begin{array}{c}28.04 .2014- \\
25.07 .2014\end{array}$ & 7.50 & 8.19 & 0.69 & 0.39 \\
\hline $\begin{array}{c}28.07 .2014- \\
31.10 .2014\end{array}$ & 8.00 & 8.06 & 0.06 & 0.49 \\
\hline $\begin{array}{c}05.11 .2014- \\
11.12 .2014\end{array}$ & 9.50 & 10.19 & 0.69 & 0.49 \\
\hline $\begin{array}{c}12.12 .2014- \\
15.12 .2014\end{array}$ & 10.50 & 11.82 & 1.33 & 0.08 \\
\hline $\begin{array}{c}16.12 .2014- \\
30.01 .2015\end{array}$ & 17.00 & 18.35 & 1.35 & 2.91 \\
\hline $\begin{array}{c}02.02 .2015- \\
13.03 .2015\end{array}$ & 15.00 & 15.17 & 0.17 & 0.32 \\
\hline $\begin{array}{c}16.03 .2015- \\
30.04 .2015\end{array}$ & 14.00 & 14.45 & 0.45 & 0.36 \\
\hline $\begin{array}{c}05.05 .2015- \\
15.06 .2015\end{array}$ & 12.50 & 12.86 & 0.36 & 0.35 \\
\hline $\begin{array}{c}16.06 .2015- \\
31.07 .2015\end{array}$ & 11.50 & 11.72 & 0.22 & 0.51 \\
\hline $\begin{array}{c}03.08 .2015- \\
10.06 .2016\end{array}$ & 11.00 & 11.02 & 0.02 & 0.41 \\
\hline $\begin{array}{c}14.06 .2016- \\
05.08 .2016\end{array}$ & 10.50 & 10.38 & -0.12 & 0.13 \\
\hline
\end{tabular}

Sources: The Bank of Russia, own calculations. 
key rate by more than 0.5 p.p.s in seven time intervals (key rate periods). ${ }^{1}$ Excluding the period of high turbulence in the mid-December 2014 and the period when there was a clear "smell" of upcoming structural surplus of liquidity (see the bottom line in Table 2), the interbank lending market interest rate was above the key rate by an average of 0.34 p.p.s. The money market interest rate was below the key rate during the final period, although it was clear that the interest rate on unsecured interbank loans should stay above the rate on Bank of Russia secured loans by a factor of credit risk premium.

Observers by themselves should consider whether the Bank of Russia's interest rate policy is successful, because the Bank has not specified the extent to which the money market interest rate is to be considered appropriately close to the key rate.

New problems of managing the money market interest rate are to emerge as a structural surplus of liquidity in the banking sector gets close. The market interest rate will initially be below the key rate, and then it is expected to near the lower bound of the interest rate corridor. The Bank of Russia will manage the short-term money market interest rate with an accuracy up to 1 p.p.

1 This value is considerable, according to the standards applied by many central banks. For example, this spread was equal to $1 / 100$ of a p.p. at the European Central Bank prior to the crisis of 2008. 